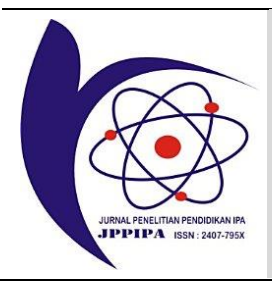

\title{
The Effect of Type and Duration of Seed Storage on Sugarcane Growth
}

\author{
Parnidi $^{1^{*}}$, Rully Hamida ${ }^{1}$ \\ ${ }^{1}$ Balai Penelitian Tanaman Pemanis dan Serat, Jl. Raya Karangploso KM 4 Kotak Pos. 199, Malang, Indonesia
}

DOI: $10.29303 /$ jppipa.v7i2.579

\section{Article Info}

Received : January $14^{\text {th }}, 2021$

Revised : March 29th, 2021

Accepted: April 11th, 2021

\begin{abstract}
Abstrack: Sugarcane propagation is mostly done by stem cuttings aged 5 to 8 months. Sugarcane seeds in the form of stalks have limited storage capacity, the germination of seeds will decrease rapidly if the seeds are stored for too long time. The high weight and volume for the use of sugarcane seeds is one of the limiting factors if planting is to be carried out far from the seed breeding place. The purpose of this study was to determine the effect of the type and storage time of sugarcane seeds on the growth of sugarcane.The research was conducted at the Karangploso Experimental Garden Balittas in January-December 2016. The research was carried out in the field using a divided plot design with 3 replications. The main plot is the type of seed, namely B1 (bud sett) and B2 (bud chip). As subplots are the storage time P0 (without storage/control), P1 (24 hours storage), P2 (48 hours storage), and P3 (72 hours storage). The results showed that the germination power of bud set did not decrease significantly. The increase in germination and first count germination was noticeable at $24-72 \mathrm{~h}$ storage compared to control. The percentage of bud chip seed germination rate decreases with increasing storage time. In the polybags phase, the growth of bud sett seeds is faster than bud chip seeds. The growth of 3 months old plants after transplanting the number of seedlings of bud sets and bud chips was not significantly different. The variables of plant height, stem diameter and number of internodes were significantly different. All the observation variables at the age of 6 months showed no significant difference between bud set seeds and bud chip seeds.
\end{abstract}

Keywords: sugarcane; seed; bud sett; bud chip; storage

Citation: $\quad$ Parnidi, P., \& Hamida, R. (2021). The Effect of Type and Duration of Seed Storage on Sugarcane Growth. Jurnal Penelitian Pendidikan IPA, 7(2), 207-212. doi:https:/ / doi.org/10.29303/jppipa.v7i2.579

\section{Introduction}

Seed is the basic material for the formation of plant yield and biomass capability. The availability of seeds of superior sugarcane varieties that are uniform, pure (not mixed with other varieties), healthy, do not suffer physical damage and are available when needed in large quantities is one of the factors determining success in sugarcane cultivation. Provision of superior and quality sugarcane seeds is the first step to increasing national sugar production. Seedlings are a very important production factor in sugarcane cultivation, because one of the factors that determines the success of planting is the availability of quality seeds (Ningrum \& Sumarni, 2014). Quality superior variety seeds affect productivity and production, yield quality and farming efficiency (Adinugraha, et al., 2016; Susilo, et al., 2018). The use of pure and quality seeds can increase production by $19 \%$ with an increase in income almost twice the additional cost of procuring these seeds (Nahdodin, 1993; Purwati \& Parnidi, 2017).

Susilo et al. (2018) in sugarcane cultivation, the provision of seeds using conventional systems is often constrained by the low production of seeds from breeders, as well as less guaranteed health and purity of seeds. So far, sugarcane propagation is mostly done 
by using the 5-8 month old stem cuttings method. Sugarcane seeds in the form of stalks have limited storage capacity, the germination of the seeds will decrease rapidly if the seeds are stored for too long. In the last few years, bud sett and bud chip cane seeds have been introduced. Currently the use of bud sett and bud chip sugarcane seeds has been widely applied not only at the breeder level but at the farmer level (ICRISAT-WWF, 2009; Kumar, 2017). From several studies, the use of bud sett and bud chip seeds has shown to be better than mule seeds. The use of bud sett or bud chip seeds for one hectare requires seeds of 1-2 tons of mule seeds or the equivalent of 15,000-20,000 eyes, while mule seeds require $7-8$ tons or the equivalent of 50,000-60,000 eyes for planting one hectare (Balittas, 2018; Purwati \& Parnidi, 2017).

Various advantages and disadvantages of bud sett or bud chip sugarcane seeds, it does not mean that the two technologies are better than mule seeds. For this reason, there are still many things from the two sugarcane seed technologies to be evaluated. Some things that still need information to complete the technology package for sugarcane seeds in the form of bud sett seeds or bud chip seeds include the optimal seed age, how the long distance seed delivery system and so on. Based on the above background, it is necessary to conduct research on the effect of the type and length of storage of seeds on the growth of sugarcane.

\section{Method}

The research was carried out at KP. Karangploso, Malang in January - December 2016. The research was carried out in the field using a divided plot design with 3 replications. The main plot is the type of seed, namely B1 (bud sett) and B2 (bud chip). As subplots are the storage time P0 (without storage/control), P1 (storage 24 hours), P2 (storage 48 hours), and P3 (storage 72 hours).

\section{Preparation of Planting Materials}

Sources of sugarcane seeds to be used are bud sets and bud chips. The sugarcane seeds are in the shape of an oval then clotted, for the bud sett, $4 \mathrm{~cm}$ each side is cut and the bud chip seeds are taken by drilling with a diameter of $\pm 2-3 \mathrm{~cm}$.

The bud sett and bud chip are put into the net (waring) and then cleaned with water to remove dirt so that it doesn't hinder the Hot Water Treatment (HWT) process. After cleaning, the HWT process is carried out, in which the bud chips are soaked in hot water at \pm 510C for 1 hour. After that, the seed treatment is carried out by soaking the bud chip in an insecticide or nematicide solution (Carbofuran 3\%) for \pm 10 minutes.
Furthermore, the bud chips were immersed in a solution of Growth Regulator + Fungicide (Mankozeb $73.8 \%$ and Karbendazim $6.2 \%$ or Atonic) for \pm 10 minutes.

\section{Planting Seeds in nursery \\ 1. Bud chip seeds}

The bud chip seeds that have been treated with hot water treatment are then planted in the nursery with a spacing of $2 \times 2 \mathrm{~cm}$ or $3 \times 3 \mathrm{~cm}$. After that the seeds are covered with soil with a thickness of $\pm 1 \mathrm{~cm}$. Watering is done 2 times a day (morning and evening) for 14 days (before being transferred to the polybag).

The seeds that have been pulled from the nursery are stored for some time to determine the resistance of the seeds. Then stored according to the treatment, namely: $0,24,48,72$ hours. If it is according to its shelf life, then the seeds are transplanted into polybags. The seeds that are transferred to the polybags are selected with uniform growth then watered and placed on top of plastic mulch so that the roots do not penetrate the soil.

\section{Bud Sett seeds}

The bud sett seeds that have been treated with hot water treatment are then stored according to the treatment, namely: 0, 24, 48, 72 hours. Then after storing the seeds they are moved to the polybags.

\section{Maintenance in polybags}

Watering the bud chip and bud sett seeds is done 2 times a day (morning and evening). Fertilization is carried out 5 days after being transferred to polybags, the fertilizer used is 25 grams of NPK fertilizer (16:16:16) dissolved in 10 liters of water for an area of 1 $\mathrm{m}^{2}$. The second fertilizer is given at the same dose after 1 month of the first fertilizer. After the seeds are $2-2.5$ months old, they can be transplanted into the land/garden.

\section{Maintenance in the Garden}

The seeds to be moved will already have 4-5 leaves (2.5-3 months old). Make planting holes 10-15 cm deep, $50 \mathrm{~cm}$ spacing between holes. Before planting, the polybags are removed carefully so as not to damage the roots. The seeds are planted in the prepared hole and covered with crumb soil to cover the original medium and irrigated. To reduce transpiration, 2/3 of the leaf blade is cut before planting. Furthermore, maintenance is carried out according to the sugarcane nursery cultivation procedure.

\section{Response Design}

Observations of the germination capacity of the bud sett seeds and the survival ability of the bud chip 
seeds were carried out at the age of 1 month after planting in the polybags. Furthermore, the growth was observed at the age of 2 months in the form of a parameter of the number of leaves.

Observations of growth in the field were carried out at the age of 3 and 6 months after planting (MAP), which consisted of: number of tillers, number of productive tillers, plant height, stem diameter, and number of internodes. The data from the observations were analyzed using variance and followed by the BNJ test with a significant level of $5 \%$

\section{Resultand Discussion}

\section{Evaluation of Bud Sett and Bud Chip Seeds in the polybag nursery phase}

The observations indicated that the germination capacity of the bud sett seeds did not decrease significantly. Germination and first count germination had a marked increase in storage 24-72 h compared to controls (Figure 1). This is because during the storage process the seeds are packaged in a paranet (waring) and put in a bamboo container (baskets) the breakdown of carbohydrates, fats and proteins into dissolved forms and translocated to the point of growth and an increase in the rate of respiration of the seeds.

The storage of seeds in waring for 72 hours showed a higher germination rate compared to 24 and 48 hours storage. This indicates that the seeds are active in metabolism even though they are in a minimal condition because they have not yet experienced growth.

Meanwhile, the percentage of bud chip seed germination capacity decreased along with the longer storage time (Figure 1). This is because storage is carried out on seeds that have grown, so that the ability of the seeds to grow (seed viability) decreases. The deterioration of seed quality is a gradual and cumulative process of decline and is irreversible due to physiological changes caused by internal factors. According to Justice \& Bass (2004); Danapriatna (2010) stated that storing seeds as long as possible will eliminate the germination and vigor of the seeds.

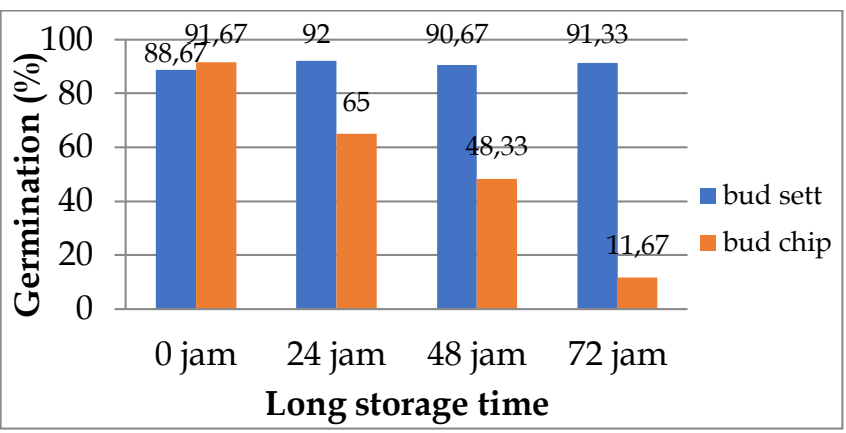

Figure 1. Comparison of the germination percentage of bud sett seeds and bud chip seeds 1 month old.
The reduced germination of sugarcane seeds is caused by the characteristics of the seeds themselves and environmental factors for storage. According to Annisa, Taryono \& Yudono (2015) sugarcane seed germination depends on the water content around the knuckle of the stem segment. Seed storage treatment causes a decrease in seed moisture content. Sugarcane planting material in the form of bud sett has advantages in terms of durability of seeds during storage because it stores quite a lot of water, but planting material in the form of a bud sett has the disadvantage of being less efficient because it requires more space for storage. Meanwhile, the bud chip seeds are smaller in size but cannot stand for long storage. Due to the small size, the water content in the seeds is low with a long storage time, so the water rust decreases and results in a decrease in the germination of the bud chip seeds.

The nature of the single eye bud of sugarcane (bud sett or bud chip) resembles recalcitrant seeds, namely the nature of the seeds which quickly lose their germination capacity because they do not have a dormancy period (Panuntun \& Wulandari, 2017). Sugarcane seeds are included in recalcitrant seeds, so special treatment is needed during storage, because these seeds cannot last long. Omoto, Abayo \& Jamoza (2007) stated that sugarcane seeds will experience a marked decrease in germination capacity after 7 days of planting delay in storage. Therefore, in the process of planting bud chip seeds, it is necessary to support an optimal storage method.

According to Danapriatna (2010); Kurniawan (2017) that packaging materials are critical to shelf life. The packaging material with too many holes can cause air exchange from outside to inside or vice versa, which is very large, as a result, the moisture content of the seeds in the material will decrease more quickly. The use of appropriate packaging materials can protect the seeds from changing environmental conditions.

Jain's research (2016) states that bud chip seeds have a relatively short shelf life, with storage at a temperature of $16^{\circ} \mathrm{C}$ and wrapped in polyethylene plastic, only able to last 10 days. According to Juprianto, Nugroho \& Suryanto (2018), bud chip seeds stored for 5 days wrapped in a tissue can produce a better percentage of shoots to grow compared to storage for 1, 3 and 7 days wrapped in tissue or without a layer of tissue. The sproutability of a single sugarcane shoot decreases rapidly due to physical shrinkage and an increase in the activity of sucrose hydrolysis enzymes such as neutral invertase (NI) and soluble acid invertase (SAI) which significantly reduce sucrose in sugarcane stalks for 3 days of storage (Siswoyo, et al., 2015). On the other hand, the width of the cutting wound on the single eye bud of sugarcane has the 
potential to accelerate the respiration process and hydrolysis of sucrose.

Table 1. Number of leaves in the set bud seed and 2 month old bud chip in polybags.

\begin{tabular}{llll}
\hline \multirow{2}{*}{ No } & $\begin{array}{l}\text { Save time } \\
\text { (hours) }\end{array}$ & \multicolumn{2}{l}{ Number of leaves per plant } \\
\cline { 3 - 4 } & 0 & $3 u d$ sett $(a)$ & Bud chip $(a)$ \\
\hline 1 & 24 & 3.32 & 2.73 \\
2 & 48 & 3.38 & 2.30 \\
3 & 48 & 3.13 & 2.03 \\
4 & 72 & 3.32 & 2.00 \\
\multicolumn{2}{l}{ Average } & 0.13 & 2.27 \\
CV $(\%)$ & 0.34 \\
\hline
\end{tabular}

Description: the numbers followed by the same letter in the same column are not significantly different based on the BNJ test at $5 \%$ level

The mean number of leaves measured in bud sett seeds was 3.32 leaves/plant, while bud chip seeds were 2.27 leaves/plant. The results of variance showed that the effect of seed storage time on the number of leaves, both bud sett and bud chip, did not show a significant difference at the $5 \%$ level (Table 1). The growth of bud sett seeds is faster than bud chip seeds that have been stored, this is because the stored bud sett seeds have already carried out the initiation phase so that when planting into the polybags, the bud sett seeds can adapt better, which is indicated by a faster growth rate. Meanwhile, the bud chip seeds that has been stored requires a longer adaptation due to wilting or a decrease in the moisture content of the seed after the seed storage treatment so that the number of bud chip seed leaves formed is lower than that of the bud sett seed.

\section{Evaluation of Bud sett seeds and Bud chip seeds in the Field}

The results showed that at the age of 3 months after planting (MAP) the number of bud sett seeds ranged from 3.7 to 4.6 shoots/clump and bud chip seeds ranged from 3.0 to 4.7 shoots/hill. Furthermore, there was an increase in the number of tillers at the age of 6 days afterwards in the bud sett seeds ranging from 4.2-4.6 shoots/clump and bud chip seeds from 3.3 to 5.2 shoots/clump. The results of the variance analisys showed that the number of clump in the bud sett seeds and bud chip seeds until the age of 6 months after planting did not show a significant difference at the $5 \%$ level (Table 2).

Table 2. Number of tillers and number of productive tillers of sugarcane seeds at the age of 3 and 6 bst

\begin{tabular}{|c|c|c|c|c|c|}
\hline \multirow{3}{*}{ No } & \multirow{3}{*}{ Treatment } & \multicolumn{2}{|c|}{ Number of tillers/clumps } & \multicolumn{2}{|c|}{ Number of productive tillers/clumps } \\
\hline & & \multicolumn{4}{|c|}{ Age (months) } \\
\hline & & 3 & 6 & 3 & 6 \\
\hline 1 & Bud sett 0 hours & $3.7 \mathrm{a}$ & $4.2 \mathrm{a}$ & $1.0 \mathrm{a}$ & $3.3 \mathrm{a}$ \\
\hline 2 & Bud sett 24 hours & $3.7 \mathrm{a}$ & $4.3 \mathrm{a}$ & $1.0 \mathrm{a}$ & $3.6 \mathrm{a}$ \\
\hline 3 & Bud sett 48 hours & $3.8 \mathrm{a}$ & $4.6 \mathrm{a}$ & $1.0 \mathrm{a}$ & $3.5 \mathrm{a}$ \\
\hline 4 & Bud sett 72 hours & $4.6 \mathrm{a}$ & $4.2 \mathrm{a}$ & $1.0 \mathrm{a}$ & $3.7 \mathrm{a}$ \\
\hline 5 & Bud chip 0 hours & $4.7 \mathrm{a}$ & $5.2 \mathrm{a}$ & $1.0 \mathrm{a}$ & $4.4 \mathrm{a}$ \\
\hline 6 & Bud chip 24 hours & $3.8 \mathrm{a}$ & $4.1 \mathrm{a}$ & $1.0 \mathrm{a}$ & $3.5 \mathrm{a}$ \\
\hline 7 & Bud chip 48 hours & $3.6 \mathrm{a}$ & $3.7 \mathrm{a}$ & $1.0 \mathrm{a}$ & $3.2 \mathrm{a}$ \\
\hline 8 & Bud chip 72 hours & $3.0 \mathrm{a}$ & $3.3 \mathrm{a}$ & $1.0 \mathrm{a}$ & $2.6 \mathrm{a}$ \\
\hline \multicolumn{2}{|c|}{ Average } & 4.04 & 4.17 & 1.00 & 3.51 \\
\hline \multicolumn{2}{|c|}{ CV (\%) } & 24.68 & 24.21 & 0.00 & 17.05 \\
\hline
\end{tabular}

Description: the numbers followed by the same letter in the same column are not significantly different based on the BNJ test at $5 \%$ level

The number of productive tillers is calculated from the sugarcane shoots that have been formed at least 2 segments. Productive tillers are a representation of the plants that will be harvested as the next planting material. At the age of $3 \mathrm{MAP}$, the number of productive tillers of bud sett and bud chip seeds was the same, namely 1 productive tiller/clump. Whereas for the age of $6 \mathrm{MAP}$, the seeds of bud sett were formed from 3,3-3,7 productive tillers/clump and bud chip seeds from 2,6-4,4 productive tillers/clumps. The results of the variety of productive tillers at age 3 and 6 MAP did not show a significant difference in all treatments (Table 2).
The measurement results of the plant height variable showed that the bud chip seeds were higher than the bud sett seeds. The 3 month old bud set seeds ranged from $81-89.22 \mathrm{~cm}$, while the bud chip seeds ranged from $87.11-101.22 \mathrm{~cm}$. Meanwhile, at the age of 6 months, the seed bud sets ranged from 182.24 to $189.39 \mathrm{~cm}$ and the bud chip seeds ranged from 192.95 to $205.25 \mathrm{~cm}$. The process of stem elongation is basically influenced by two dominant elements, namely segment differentiation and lengthening of sugarcane segments. Bud chip seeds have longer internodes than bud sett seeds, thus supporting plant height (Table 3). The results of variance on plant height parameters showed that at the age of 3 months there was a significant 
difference, while the age of 6 months did not show a significant result.

The same was shown in the variable plant diameter and number of internodes. Where the bud chip seeds has a larger diameter and a larger number of internodes than the bud sett seeds. The results of variance showed that the measurement of plant diameter and number of internodes at 3 months of age showed a significant difference, but at 6 months of age it did not show a significant difference, both in the bud sett seeds and in the bud chip seeds.

Table 3. Plant height, stem diameter and number of sugarcane seed joints at ages 3 and 6 late

\begin{tabular}{|c|c|c|c|c|c|c|c|}
\hline \multirow{3}{*}{ No } & \multirow{3}{*}{ Treatment } & \multirow{2}{*}{\multicolumn{2}{|c|}{$\begin{array}{l}\text { Plant height } \\
\text { (cm) } \\
\text { Age (months) }\end{array}$}} & \multicolumn{2}{|c|}{ Rod diameter (mm) } & \multicolumn{2}{|c|}{$\begin{array}{l}\text { Number of sections/ } \\
\text { clump }\end{array}$} \\
\hline & & & & Age $(\mathrm{m}$ & & Age (1 & \\
\hline & & 3 & 6 & 3 & 6 & 3 & 6 \\
\hline 1 & Bud sett 0 days & $89.0 \mathrm{ab}$ & 189.3 a & $17.7 \mathrm{abc}$ & $23.3^{a}$ & $4.4^{\mathrm{a}}$ & 8.7 a \\
\hline 2 & Bud sett 1 days & $89.2 \mathrm{ab}$ & 187.2 a & $17.0 \mathrm{bc}$ & $22.5^{\mathrm{a}}$ & $4.1 \mathrm{ab}$ & $8.4^{\mathrm{a}}$ \\
\hline 3 & Bud sett 2 days & $85.9 \mathrm{ab}$ & 187.0 a & $16.2 \mathrm{bc}$ & $22.1^{a}$ & $4.0 \mathrm{ab}$ & $8.4^{\mathrm{a}}$ \\
\hline 4 & Bud sett 3 days & $81.0 \mathrm{ab}$ & 182.2 a & $15.7^{c}$ & $21.5^{a}$ & $3.8 \mathrm{ab}$ & $7.8^{a}$ \\
\hline 5 & Bud chip 0 days & 99.4 a & 192.9 a & $17.8 \mathrm{abc}$ & $22.8^{a}$ & $3.6 \mathrm{ab}$ & 9.7 a \\
\hline 6 & Bud chip 1 days & 101.2 a & 205.2 a & $19.4 a b c$ & 24.9 a & $3.8 \mathrm{ab}$ & $10.4^{\mathrm{a}}$ \\
\hline 7 & Bud chip 2 days & $98.8^{a}$ & 192.9 a & $17.7 \mathrm{abc}$ & $22.7 \mathrm{a}$ & $3.2 \mathrm{ab}$ & 8.9 a \\
\hline 8 & Bud chip 3 days & $87.1 \mathrm{ab}$ & $197.4^{\mathrm{a}}$ & $17.3 \mathrm{bc}$ & $21.9 \mathrm{a}$ & $2.8 \mathrm{ab}$ & $9.4^{\mathrm{a}}$ \\
\hline \multicolumn{2}{|c|}{ Average } & 87.2 & 192.2 & 18.4 & 22.9 & 3.3 & 8.9 \\
\hline \multicolumn{2}{|c|}{ CV (\%) } & 7.7 & 4.9 & 7.9 & 6.2 & 22.6 & 10.5 \\
\hline
\end{tabular}

Description: the numbers followed by the same letter in the same column are not significantly different based on the BNJ test at $5 \%$ level.

There was no effect of storage time on the growth parameters of sugarcane seeds when they were moved to the field using either bud sett or bud chip seeds, because the conditions at the time of planting in polybags showed the same thing and when planted in the field showed no difference. The highest yield was shown in bud chip seeds treatment with a storage period of 1 day.

\section{Conclusion}

The shape of the seeds greatly affects the storage capacity of the seeds. The germination of bud sett seeds showed better storage capacity than bud chip seeds. The bud chip seeds showed that they could not stand storage for more than 24 hours because they would experience a very large reduction in germination (89.33\%). Meanwhile, in the buds sett seeds, after 72 hours of storage, the germination capacity still reached 91.33\%. Plant growth from bud sett seeds or bud chip seeds that survive storage after planting in the field up to 6 months of age did not show a significant difference.

\section{References}

Adinugraha, I., Nugroho, A., \& Wicaksono, P. (2016). Pengaruh asal bibit bud chip terhadap fase vegetatif tiga varietas tanaman tebu (Saccharum officinarum L .). Jurnal Produksi Tanaman, 4(6), 468-477. [Indonesian]
Annisa, F., Taryono, T., \& Yudono, P. (2017). Pengaruh Lama Penyimpanan Bagal terhadap Kualitas dan Perkecambahan Mata Tunas Tunggal Tebu (Saccharum officinarum L.). Vegetalika, 4(4), 48-56. doi:https://doi.org/10.22146/veg.23950. [Indonesian]

Balittas. (2018). Pembibitan Tebu. Retrieved from http://perkebunan.litbang.pertanian.go.id/pem bibitan-tebu [Indonesian]

Danapriatna, N. (2010). Pengaruh penyimpanan terhadap viabilitas benih kedelai. Malang. [Indonesian]

ICRISAT-WWF. (2009). Sustainable Sugarcane Initiative. India: ICRISAT. Retrieved from http://www.agsri.com/images/documents/ssi Lssi_manual_2012.pdf

Jain, R. (2016). Bud chip nurseries - history, methods of raising, results of germination studies. Retrieved from

http://www.agsri.com/images/documents/sy mposium_1/Pdf files of PPTs/Technical Session I/Bud chip nurseries_IISR.pdf

Juprianto, M., Nugroho, A., \& Suryanto, A. (2018). Kajian waktu dan cara penyimpanan bibit TEBU (Saccharum officinarum L.) varietas ps 881 metode bud chip pada pertumbuhan vegetatif awal. Jurnal Produksi Tanaman, 6(3), 350-354. [Indonesian]

Justice, O. L., \& Bass, L. N. (2004). Principles and practices of seed storage. (O. L. Justice \& L. N. Bass, Eds.), Washington, DC (1st ed.). New York: Washington, DC. 
Kumar, T. S. (2017). Bud chip method: A potential technology for sugarcane (Saccharum officinarum) cultivation. Medicinal Plant Studies, 5(3), 355-357.

Kurniawan, J. (2017). Pengaruh penyimpanan terhadap viabilitas benih kedelai. Univertas Jambi. Jambi. [Indonesian]

Nahdodin, (1993). Penyediaan bibit tebu berkualitas. Permasalahan dan penanggulangannya. Gula Indonesia. XVIII (3): 39-41. [Indonesian]

Ningrum, M. K., \& Sumarni, T. (2014). Pengaruh naungan pada teknik pembibitan bud chip tiga varietas tebu (Saccharum officinarum L .). Jurnal Produksi Tanaman Vol., 2(3), 260-267. [Indonesian]

Omoto, G., Abayo, G. O., \& Jamoza., J. E. (2007). Effect of delayed planting seedcane on sugarcane germination, growth rate and yield. Kenya.

Panuntun, H. T., \& Wulandari, R. A. (2017). Pengendalian Mutu Benih Tebu (Saccharum officinarum L.) Mata Tunas Tunggal Menggunakan Pengaturan Kadar Lengas Media Serbuk Abu Sekam Padi, Vegetalika, 6(1), 46-58. [Indonesian]

Purwati, R. D., \& Parnidi. (2017). Pengadaan Benih Tebu bermutu. In E. et al Sulistyowati (Ed.), Monograp Balittas (1st ed., Vol. 1, pp. 33-54). Malang: IAARD Press. [Indonesian]

Siswoyo, T. A., Oktavianawati, I., Sugiharto, B., \& Murdiyanto, U. (2015). Perubahan Kandungan Sukrosa dan Aktivitas Invertase pada Batang Tebu Selama Pemanenan. Zuriat, 17(2), 2006. https://doi.org/10.24198/zuriat.v17i2.6739 [Indonesian]

Susilo, H., Soelistyono, R., \& Maghfoer, D. (2018). Pengaruh perlakuan air panas dan media tanam terhadap pertumbuhan bibit tebu ( Saccharum officinarum L ) varietas PS 881. J. Produksi Tanaman, 6(3), 447-454. [Indonesian] 